\title{
小児前腕骨骨幹部骨折の再骨折例の検討
}

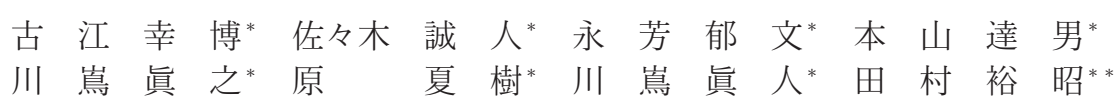

\section{Refractures of the Midshaft Forearm in Children}

Yukihiro Furue*, Makoto Sasaki*, Ikufumi Nagayoshi*, Tatsuo Motoyama*, Masayuki Kawashima*, Natsuki Hara*, Mahito Kawashima*, and Hiroaki Tamura**

小・中学生の前腕両骨骨幹部骨折（中 3 分の 1）を調査し，再骨折例を検討した。2003 年 11 月以降, 22 例の対象前腕骨骨折を治療し，そのうち 6 例に再骨折をおこし，うち 1 例は再々骨折をおこした。 6 例 全例 10 歳以上であった。 5 例は若木骨折で，角状変形と回内外可動域制限が残存し，完全な骨癒合を得 ていなかった。4例の受傷機転がスポーツによるものであった。再骨折の治療は，5例に対しては手術を 行い，良好な成績を得た。10歳以上，完全に癒合していない若木骨折，角状变形の残存，回内外可動域 制限は再骨折の要因と考えられた。また，早すぎるスポーツ復州む要因と考えられる。

We reviewed the clinical results and fracture profile of the diaphyseal refracture of the forearm (middle third of the shaft) in primary or junior high school students. From November 2003, 22 midshaft forearm fractures were treated at our hospital. Of these refractures had occured in six, and one had a second refracture. Excellent results were achieved by operative treatment in five patients. Refracture is thought to occur in ages older than 10, due to greenstick fracture which has not fully healed, residual angulation deformity, limitation of range of forearm supination and pronation, or return to sport activity too early. Care should be taken when treating greenstick fractures in higher grades.

Key words : refracture (再骨折), forearm fracture（前腕骨骨折), children（小児）

\section{は じめに}

小児前腕骨骨幹部骨折の治療に於いては，まれに再 骨折をおこすことがあり注意を要すが，再骨折に着目 した報告は少ない. 今回, 当院での再骨折例の検討を 行ったので報告する.

\section{対象}

2003 年 11 月以降に当院で加療した, 小・中学生の 前腕両骨骨幹部骨折 (中 3 分の 1) 22 例を調查した. 男性 18 例，女性 4 例，平均年齢は 10.4 歳である。 そ のうち再骨折を起こした症例は 6 例で, 男性 5 例, 女 性 1 例, 年齢は 10 歳から 13 歳, 平均 11.8 歳であっ
た. 1 例は再骨折治療中, 再々骨折をおこした。一方, 再骨折を起こさなかった症例は 16 例で, 男性 13 例, 女性 3 例, 平均年齢 9.6 歳であった.

\section{結果}

再骨折例の初回骨折プロフィールを表に示す（表 1 ). 5 例は若木骨折で, ギプス固定による保存療法が行わ れ，13 歳の完全骨折例に対しては，髄内釘固定によ る手術が行われていた。

再骨折のプロフィールを表に示す（表 2 ). 初回骨 折からの期間は 40 日から 215 日, 平均 99.4 日であっ た. 受傷機転ではスポーツによる受傷が 4 骨折あった. 再骨折直前のレントゲン所見では，初回治療にて手術

\footnotetext{
* 川嶌整形外科病院 Kawashima Hospital of Orthopaedic Surgery, Oita, Japan

**かわしまクリニック Kawashima Clinic, Oita, Japan
} 
表 1 初回骨折プロフィール

\begin{tabular}{|c|c|c|c|c|c|}
\hline 症例 & 性別 & 年齢 & 受傷機転 & 骨折型 & 治療方法 \\
\hline (1) & 男 & 13 & 自転車で転倒 & 若木 & $\begin{array}{c}\text { (前医) } \\
\text { ギプス固定 } 28 \text { 日 }\end{array}$ \\
\hline (2) & 男 & 10 & 体育中転倒 & $\begin{array}{c}\text { 橈骨 若木 } \\
\text { 尺骨 塑性変形 }\end{array}$ & $\begin{array}{l}\text { (前医) } \\
\text { ギプス固定 }\end{array}$ \\
\hline (3) & 男 & 12 & バスケット & 若木 & $\begin{array}{c}\text { 徒手整復 } \\
\text { ギプス固定 } 40 \text { 日 }\end{array}$ \\
\hline (4) & 女 & 10 & バレーボール & 若木 & $\begin{array}{c}\text { 徒手整復 } \\
\text { ギプス固定 } 44 \text { 日 }\end{array}$ \\
\hline (5) & 男 & 11 & 鉄棒から転落 & 若木 & $\begin{array}{c}\text { 徒手整復 } \\
\text { ギプス固定 } 45 \text { 日 }\end{array}$ \\
\hline (6) & 男 & 13 & 崖から転落 & 完全 & $\begin{array}{c}\text { 橈骨 K-wire 骾内釘 } \\
\text { 尺骨 } \mathrm{K} \text {-wire 髄内釭 } \\
\text { (シーネ固定 } 14 \text { 日) }\end{array}$ \\
\hline
\end{tabular}

表 2 再骨折プロフィールと直前の所見

* : 2 方向 X p での癒合した皮質骨数を呈示

症例(1)は再々骨折をおこし, (1) と表示

\begin{tabular}{c|c|c|c|c|c|c|c|c}
\hline \hline 症例 & $\begin{array}{c}\text { 初回骨 } \\
\text { 折から }\end{array}$ & 受傷機転 & 橈骨变形 & 尺骨变形 & $\begin{array}{c}\text { 橈骨 } \\
\text { 癒合* }\end{array}$ & $\begin{array}{c}\text { 尺骨 } \\
\text { 癒合* }\end{array}$ & 回内 & 回外 \\
\hline (1) & 40 日 & 歩行中転倒 & 掌側凸 14 度 & 掌側凸 7 度 & 3 & 1 & 60 & 0 \\
\hline (1) & 59 日 & 野球 & 掌側凸 14 度 & 掌側凸 7 度 & 3 & 2 & 70 & 45 \\
\hline (2) & 77 日 & 自転車で転倒 & $\begin{array}{c}\text { 背側凸 } 20 \text { 度 } \\
\text { 尺側凸 } 12 \text { 度 }\end{array}$ & 橈側凸 18 度 & 1 & 4 & $?$ & $?$ \\
\hline (3) & 215 日 & バスケット & 掌側凸 7 度 & なし & 4 & 3 & 90 & 90 \\
\hline (4) & 57 日 & 歩行中転倒 & 掌側凸 17 度 & 掌側凸 10 度 & 1 & 1 & 70 & 60 \\
\hline (5) & 106 日 & サッカー & 尺側凸 16 度 & なし & 3 & 2 & 40 & 70 \\
\hline (6) & 142 日 & サッカー & なし & なし & 2 & 2 & 75 & 30 \\
\hline
\end{tabular}

を行った 1 例以外は角状变形を残しており, 全例が完 全な骨癒合をまだ得ていない所見であった。また， 1 例を除き回内外可動域制限が残存していた.

一方，再骨折を起こさなかった症例は，若木骨折 10 例, 完全骨折 6 例で, 保存療法を 9 例に, 手術療 法を 7 例に行っていた. 最終経過観察時に, レントゲ ン像での角状变形を残す例を橈骨に 6 例, 尺骨に 2 例 認めたが, 全例骨癒合は得られていた。 回内外可動域 は 2 例のみに回内制限を認めた（表 3 ）.

再骨折例に対しては，再々骨折 1 例と他 4 例には手 術を行い, 全例骨癒合が得られ, 変形や可動域制限を ほぼ残さず，優れた成績が得られた。1例には保存的 加療を行い, 経過観察中である (表 4).

\section{考察}

小児前腕骨骨幹部骨折の再骨折率は $16.2 \%{ }^{3)}, 14.7$ \% ${ }^{1)}$ との報告がある。再骨折をおこす要因は，(1)年齢 が高い，(2)若木骨折，(3)固定期間が不十分，(4)整復が 不十分（角状変形の残存）などが報告されてい

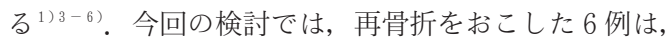
全例 10 歳以上であり，手術を受けた完全骨折例 1 例 を除いた 5 例は，角状変形が残存し，完全な骨癒合を 得ていない若木骨折の症例であった。

服部ら ${ }^{4)}$ は年齢が高くなるにつれて骨癒合の完成す る期間が遷延し，10 歳以上では 10 歳未満に比し，有 意に期間が長くなると述べている，骨癒合の完成が遅 れることに反して，10 歳以上の年代では一般にスポー 
表 3 再骨折をおこなさかった症例群

\begin{tabular}{|c|c|c|c|c|c|c|c|}
\hline 骨折型 & 治療方法 & 症例数 & 年齢 & 橈骨変形 & 尺骨変形 & 回内 & 回外 \\
\hline \multirow[t]{3}{*}{ 完全 } & \multirow[t]{3}{*}{ 手術 } & 1 & 6 & 背側凸 15 度 & なし & 90 & 90 \\
\hline & & 1 & 6 & なし & なし & 70 & 90 \\
\hline & & 4 & $7,11,14,14$ & なし & なし & 90 & 90 \\
\hline \multirow[t]{8}{*}{ 若木 } & 手術 & 1 & 9 & なし & なし & 90 & 90 \\
\hline & \multirow[t]{7}{*}{ ギプス } & 1 & 11 & $\begin{array}{c}\text { 掌側凸 } 6 \text { 度 } \\
\text { 橈側凸 } 10 \text { 度 }\end{array}$ & なし & 80 & 90 \\
\hline & & 1 & 11 & なし & 橈側凸 20 度 & 90 & 90 \\
\hline & & 1 & 7 & 背側凸 10 度 & なし & 90 & 90 \\
\hline & & 1 & 10 & 背側凸 12 度 & なし & 90 & 90 \\
\hline & & 1 & 6 & 掌側凸 10 度 & なし & 90 & 90 \\
\hline & & 1 & 10 & 掌側凸 12 度 & 橈側凸 10 度 & 90 & 90 \\
\hline & & 3 & $9,10,12$ & なし & なし & 90 & 90 \\
\hline
\end{tabular}

表 4 再骨折の治療成績

* : Grace \& Eversmann の評価 ${ }^{2)}$

症例(6) は経過観察中

\begin{tabular}{|c|c|c|c|c|c|c|c|c|}
\hline 症例 & 治療方法 & 橈骨変形 & 尺骨変形 & $\begin{array}{l}\text { 橈骨 } \\
\text { 癒合 }\end{array}$ & $\begin{array}{l}\text { 尺骨 } \\
\text { 癒合 }\end{array}$ & 回内 & 回外 & 評価* \\
\hline (1) & ギプス固定 29 日 & 掌側凸 14 度 & 掌側凸 7 度 & 4 & 2 & 70 & 45 & 不可 \\
\hline (1) ${ }^{-}$ & $\begin{array}{l}\text { 橈骨 K-wire 䯣内釭 } \\
\text { 尺骨 K-wire 䯣内釘 }\end{array}$ & なし & なし & 4 & 4 & 90 & 90 & 優 \\
\hline (2) & $\begin{array}{l}\text { 橈骨 K-wire 䯣内釘 } \\
\text { 尺骨徒手整復 }\end{array}$ & なし & 橈側凸 7 度 & 4 & 4 & 90 & 90 & 優 \\
\hline (3) & $\begin{array}{l}\text { 橈骨 K-wire 䯣内釭 } \\
\text { 尺骨 K-wire 骾内釭 }\end{array}$ & なし & なし & 4 & 4 & 90 & 90 & 優 \\
\hline (4) & $\begin{array}{l}\text { 橈骨 K-wire 䯣内釭 } \\
\text { 尺骨 K-wire 䯣内釭 }\end{array}$ & なし & なし & 4 & 4 & 90 & 90 & 優 \\
\hline (5) & $\begin{array}{l}\text { 橈骨 plate 固定 } \\
\text { 尺骨 plate 固定 }\end{array}$ & 尺側凸 12 度 & なし & 4 & 4 & 90 & 90 & 優 \\
\hline (6) & $\begin{array}{l}\text { 徒手整復 } \\
\text { ギプス固定 } 60 \text { 日 }\end{array}$ & $\begin{array}{l}\text { 掌側凸 } 8 \text { 度 } \\
\text { 尺側凸 } 12 \text { 度 }\end{array}$ & 背側凸 10 度 & 4 & 3 & 90 & 70 & \\
\hline
\end{tabular}

ツ活動を始める時期でもあり，年齢の因子は，骨癒合 の遷延という内的要因と, 早すぎるスポーツ復帰とい う外的要因を含んでいると考えられる．小学校高学年 以降のスポーツ活動は少なくとも完全な骨癒合が得ら れるまでは待つべきだと考える.

若木骨折は完全骨折に比べ，初診時は安易に捉えが ちであるが，骨癒合の観点からは長引くことがあり， 骨癒合が完全に得られるまでは注意が必要である. Schwarz $^{5)}$ はこの理由として, 若木骨折で角状变形が
残ると, 非接触部の圧迫力が不足するために同部の骨 新生が阻害され，長期にわたって骨癒合が完成しない と述べている，骨癒合を遷延させないという観点から， Gruber $^{3)}$ やSchwarz らは，若木骨折の整復時に完全 骨折にしてしまう方法を支持している．完全骨折では 再骨折率が低くなるため有効と考えられるが，一方で この方法は, 骨折部の不安定性を増すことから, 確実 なギプス固定手技を要する。

また，小児前腕骨骨折での角状变形の許容範囲は， 
未だ議論の的であるが，10 歳以上の骨幹部骨折では 10 度から 15 度以下が許容範囲とされている ${ }^{4)}$. 当然, 角状変形が大きいと骨癒合の遅れにつながり，回内外 可動域制限をきたすことにもなるが，症例(6)ように 手術で解剖学的に整復しても骨癒合が遷延し, 可動域 制限を残す例むあり，逆に角状変形が残っても可動域 制限をきたさない症例も経験するところである。しか し, 角状変形が残存し, 可動域制限屯残っている症例 に再骨折が多く発生しており，角状变形を残した例で は，骨癒合と可動域の改善を注意深く観察する必要が あると考える。

\section{ま と め}

1 : 小中学生の前腕両骨骨幹部骨折の再骨折例を調査 した.

2 ： 10 歳以上，若木骨折で完全な骨癒合が得られて いない, 角状変形を残し，回内外可動域制限があ る症例は注意深く観察すべきである.
3 : スポーツ活動の復鹵は骨癒合の完成まで控えるべ きである。

\section{文献}

1) Bould, M., Bannister, G. C. : Refractures of the radius and ulna in children. Injury, $30: 583-586$, 1999.

2) Grace, T. G., Eversmann, C. W. W. : Forearm fractures. J. Bone Joint Surg., 62-A : 433-438, 1980.

3) Gruber, R., von Laer, L. R. : The etiology of the refracture of the forearm in childhood. Aktuelle Traumatol., 9 : 251-259, 1979.

4）服部匡次ほか：小児前腕骨骨幹部骨折の治療法. 日小 整会誌， $14 ： 137-142 ， 2005$.

5) Schwarz, N., et al. : Refracture of the forearm in children. J. Bone Joint Surg., 78-B : 740-744, 1996.

6) Tredwell, S. J., Van Peteghem, K., Clough, M. : Pattern of forearm fractures in children. J. Pediatr. Orthop., 4 : 604-608, 1984 